\title{
EFFECTS OF CLIMATE CHANGE ON COASTAL FRESH
}

\section{GROUNDWATER RESOURCES}

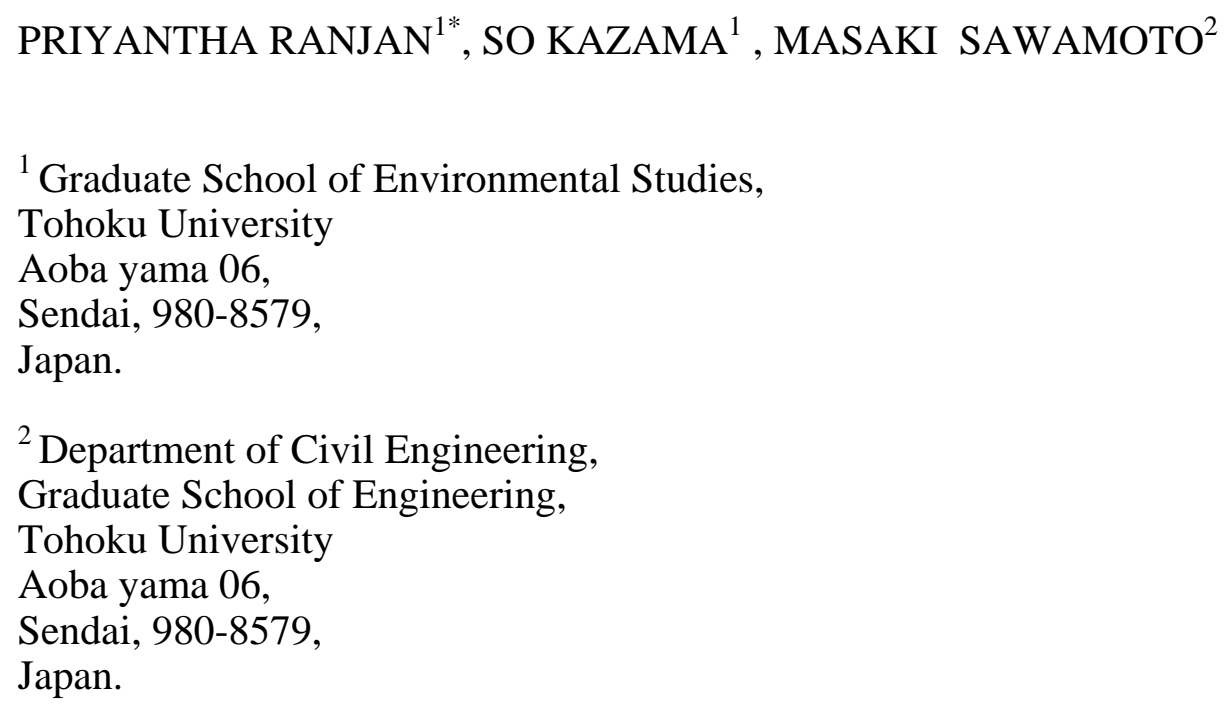

* Corresponding Author

Dr. PRIYANTHA RANJAN

Graduate School of Environmental Studies, Tohoku University

Aoba yama 06, Sendai, 980-8579, Japan.

Tel: +81-22-795-7458 (office) +81-90-3641-1196 (residence)

Fax: +81-22-295-7458

Email: ranjan@kaigan.civil.tohoku.ac.jp 


\title{
EFFECTS OF CLIMATE CHANGE ON COASTAL FRESH \\ GROUNDWATER RESOURCES
}

\begin{abstract}
This study evaluates the impacts of climate change on fresh groundwater resources specifically salinity intrusion in water resources stressed coastal aquifers. Our assessment used the Hadley Centre climate model, HadCM3 with high and low emission scenarios (SRES A2 and B2) for years 2000-2099. In both scenarios, the annual fresh groundwater resources losses indicate an increasing long-term trend in all stressed areas, except in the northern Africa / Sahara region. We also found that precipitation and temperature individually did not show good correlations with fresh groundwater loss. However, the relationship between the aridity index and fresh groundwater loss exhibited a strong negative correlation. We also discuss the impacts of loss of fresh groundwater resources on socio-economic activities, mainly population growth and per capita fresh groundwater resources.
\end{abstract}

\section{Abbreviated Title}

Climate change and coastal fresh groundwater resources 


\section{Introduction}

Atmospheric carbon dioxide levels have continually increased since the 1950s. The continuation of this phenomenon may significantly alter global and local climate characteristics, including temperature and precipitation. Climate change can have profound effects on the hydrologic cycle through precipitation, evapotranspiration, and soil moisture with increasing temperatures. The hydrologic cycle will be intensified, with more evaporation and more precipitation. However, the extra precipitation will be unequally distributed around the globe. Some parts of the world may see significant reductions in precipitation, or major alterations in the timing of wet and dry seasons (IPCC, 2001). Information on the local or regional impacts of climate change on hydrological processes and water resources is becoming more important. The effects of global warming and climatic change require multidisciplinary research, especially when considering hydrology and global water resources (Hugo et al, 1996; Arnell, 1999, 2004; Hulme, 1999; Eckhardta and Ulbrichb, 2003; Gertena et al, 2004; Hitz and Smith, 2004; Labat et al, 2004).

Previous studies have typically coupled climate change scenarios with hydrological models, and have generally investigated the impact of climate change on water resources in different areas (e.g.Gleick, 1987; Loaiciga et al, 1996, Bobba et al, 1997; DETR, 1997; Arnell,1999; Najjar,1999 and Mimikou et al ,2000). DETR (1997) and Arnel (1999) indicated areas experiencing water resources stress due to future climate change. They suggested that stressed countries would be concentrated in southern and northern Africa, around the Mediterranean and in the Middle East, southern Asia and the Indian subcontinent, Central America, and large parts of Europe. They predicted that as of 2025, these countries will be adversely affected by 
climate change and show an increase in water resources stress. By the 2050s and 2080s, additional countries in southern Africa will move into the stressed class and pressures will increase most rapidly in Africa and parts of southern Asia and Eastern Europe (Arnell, 1999).

When considering water resources in coastal zones, coastal aquifers are important sources of freshwater. However, salinity intrusion can be a major problem in these zones. Salinity intrusion refers to replacement of freshwater in coastal aquifers by saltwater. It leads to a reduction of available fresh groundwater resources. Changes in climatic variables can significantly alter groundwater recharge rates for major aquifer systems and thus affect the availability of fresh groundwater. Salinisation of coastal aquifers is a function of the reduction of groundwater recharge and results in a reduction of fresh groundwater resources.

Estimates of global warming are generally based on the application of general circulation models (GCMs), which attempt to predict the impact of increased atmospheric $\mathrm{CO}_{2}$ concentrations on weather variables. The GCM scenarios indicate that global warming has been increasing during recent decades and that the trend may become stronger in the future. Because of the complex mechanics and the model structure, different GCMs produce different predictions (Semmler and Jacob, 2004). However, despite differing predictions, trends in climate variables were consistent (IPCC, 2000). In this study we focus on results from the Hadley center GCM (HadCM3) and include two SRES scenarios; a high emission scenario (SRESA2) and a low emission scenario (SRES-B2). The selected emission scenarios express different results of climate change and population growth. The A2 scenario 
can be generally described as a pessimistic future. It gives high $\mathrm{CO}_{2}$ emissions and related extreme climate impacts. A2 scenario also describes a world with high population growth, relatively slow economic growth and technological change. The B2 scenario may be described as a more optimistic future. Population growth is intermediate and $\mathrm{CO}_{2}$ emissions are steadily reduced, resulting in lower levels of climate forcing (IPCC, 2001).

To assess the impacts of potential climate change on fresh groundwater resources, we focus on changes in groundwater recharge and sea level rise on the loss of fresh groundwater resources in water resources stressed coastal aquifers.

\section{Methodology and data sources}

\subsection{Numerical modeling of salinity intrusion}

Many models have been developed to study saltwater intrusion. They range from relatively simple analytical solutions to complex numerical models. Studies involving the movement of freshwater and saltwater in coastal aquifer systems are classically studied using two different approaches (Reilly and Godman, 1985). In the first approach, freshwater and saltwater are assumed completely immiscible and a sharp interface exists between two zones. In the second approach, freshwater and saltwater are assumed to be in a dynamic equilibrium resulting from advection and dispersion within the aquifer. Since the main aim of this study is to evaluate longterm behavior of coastal groundwater systems, the sharp interface model is more appropriate for this study. 
Sharp interface models couple freshwater and saltwater flow based on the continuity of flux and pressure. In this approach, together with Dupuit approximation for each flow domain, the equation of continuity may be integrated vertically to develop the following system of differential equations (Bear, 1999).

$$
\begin{aligned}
& \frac{\partial}{\partial x}\left[K_{f x}\left(h^{f}-h^{i}\right) \frac{\partial h^{f}}{\partial x}\right]+\frac{\partial}{\partial y}\left[K_{f y}\left(h^{f}-h^{i}\right) \frac{\partial h^{f}}{\partial y}\right]+q_{f}=S_{f} \frac{\partial h^{f}}{\partial t}-\theta\left[(1+\delta) \frac{\partial h^{s}}{\partial t}-\delta \frac{\partial h^{f}}{\partial t}\right]+\alpha \theta \frac{\partial h^{f}}{\partial t} \\
& \frac{\partial}{\partial x}\left[K_{s x}\left(h^{i}-z^{b}\right) \frac{\partial h^{s}}{\partial x}\right]+\frac{\partial}{\partial y}\left[K_{s y}\left(h^{i}-z^{b}\right) \frac{\partial h^{s}}{\partial y}\right]+q_{s}=S_{s} \frac{\partial h^{s}}{\partial t}+\theta\left[(1+\delta) \frac{\partial h^{s}}{\partial t}-\delta \frac{\partial h^{f}}{\partial t}\right]
\end{aligned}
$$

The location of the interface elevation $\left(h^{\mathrm{i}}\right)$ is given by

$$
h^{i}=\frac{\rho_{s}}{\rho_{s}-\rho_{f}} h^{s}-\frac{\rho_{f}}{\rho_{s}-\rho_{f}} h^{f}
$$

where $K_{f}$ and, $K_{s}$ represent the hydraulic conductivity in fresh and salt water regions. $h^{f}$ and, $h^{s}$ are the piezometric heads of freshwater and saltwater regions and $q_{f}, q_{s}$ are flow rate in fresh and salt water respectively. Storage coefficients in fresh and salt water regions are given by $S_{f}$ and $S_{s .} \theta$ is the porosity of the aquifer media. $\rho_{f}$ and $\rho_{s}$ are specific weight in fresh and salt water. $\alpha$ is a parameter which can take the value of either 1 or 0 according to the type of the aquifer; $\alpha=1$ for unconfined aquifers and $\alpha=0$ for confined aquifers.

From equations (1) and (2), it is possible to derive a numerical model using implicit finite difference techniques. To solve the two simultaneous linear algebraic 
difference equations, the Strongly Implicit Procedure -SIP (Remson et al, 1971) was used as a suitable numerical technique. Empirical evidence suggests that for cases of flow in heterogeneous or anisotropic media, the strongly implicit procedure is much more efficient than other methods and it does not depend upon the complexity of the problem (Essaid 1986).

\subsubsection{Fresh groundwater loss due to salinisation}

The concept of freshwater - saltwater interface can be used to estimate fresh groundwater resources in coastal aquifers. Increases in groundwater recharge shifts the salinity interface seaward and decreases in recharge shift it landward (interface 2). This interface movement changes the available fresh groundwater resources in the aquifer. As illustrated in Fig. 1, when the aquifer is totally filled with freshwater (interface 1), the freshwater loss is zero. The landward movement of the salinity interface leads to reduce freshwater amount in the aquifer. When the salinity interface coincides with piezometric head (interface 3), the whole aquifer fills with saltwater and indicates that freshwater loss is $100 \%$.

\section{Approximate location of Fig. 1}

\section{3 regions with water resources stress}

Based on the water resources stressed regions described by DETR (1997) and Arnel, (1999), five major regions experiencing water stress have been considered. The countries in these regions likely would experience the greatest adversewater resources impact of climate change. Coastal zones in Central America (CAM) Southern Africa (SAF) and Northern Africa / Sahara (SAH), around the 
Mediterranean (MED) and in the Southern Asia (SAS) have been selected to assess the change in fresh groundwater resources due to salinity intrusion (Fig 2a). These regions can be categorized into different climate groups. Based on the Koppen’s climate classification (FAO) the five regions locate in monsoon/subtropical, mediterranean, tropical, and desert climates. The hydro-geological properties of the regions were obtained from the Global Groundwater Information System, developed by IGRAC (2004). To simulate the effect of sea level rise, data was obtained from the PSMSL data base (Permanent Service for Mean Sea Level) based on historical trends and future predictions. Table 1 summarizes the climatic, sea level rise, and hydro-geological characteristics of the five selected regions.

Approximate location of Fig. 2

Approximate location of Table 1

\subsection{Estimation of loss of fresh groundwater resources to due climate changes}

This study uses climate change scenarios developed from Hadley Centre climate simulations (HadCM3). The climate data is available at a spatial resolution of 2.5 degree of latitude by 3.75 degree of longitude, which is equivalent to a surface resolution of approximately $417 \mathrm{~km} \times 278 \mathrm{~km}$ at the equator. The study areas are represented by only a few grid points at this coarse resolution $\left(2.5^{\circ} \times 3.75^{\circ}\right)$. The grid cells along the seaward boarder were selected to represent coastal areas (Fig 2b).

We calculate the water balance on monthly time-step for each cell, treating each cell as a separate catchment. Evaporation was calculated using the Penman Monteith formula using CROPWAT computer model. Assuming that the groundwater is replenished when precipitation exceeds actual evapotranspiration, groundwater 
recharge was estimated as the difference between precipitation and evapotranspiration. The estimated monthly recharge was used to model the saltwater-freshwater interface and calculate the average annual fluctuation of the interface for five selected coastal aquifers. The model was run to simulate changes in interface on a monthly time step, although annually averaged values were saved as output. This average annual change in the freshwater-saltwater interface was used to estimate the annual change in fresh groundwater resources due to salinity intrusion over a 100 year period.

\section{Results and Discussions}

\subsection{Loss of fresh groundwater resources over the next century}

In selected five regions; Central America (CAM), Southern Africa (SAF), Northern Africa / Sahara (SAH), Southern Asia (SAS) and the Mediterranean (MED). The average annual change in fresh groundwater resources highlights the complexity, consequences, and feedbacks of potential climate change. These results demonstrate that future fluctuations in fresh groundwater resources clearly indicate a long-term trend of increasing loss, except in northern Africa / Sahara region for both high and low emission scenarios.

Approximate location of Fig. 3 and Fig. 4

Over the next century, the linear regressions between loss of fresh groundwater resources (percentage loss) versus time show different relationships for five selected regions. As shown in Fig 3a and Fig 4a, the annual fluctuation of loss of fresh groundwater resources display short term trends in Mediterranean and southern Asian regions, while showing long term trends in other three regions for both 
scenarios. The Mediterranean region expresses an overall long term increments of 0.028 percent annual fresh groundwater loss in SRES A2 and 0.0005 percent annual fresh groundwater loss in SRES B2 scenario. The southern Asian region also showed short term variations and long term trends with 0.075 and 0.078 percent fresh groundwater loss per year for A2 and B2 scenarios respectively.

One outlier is the slight negative gradient in the northern Africa / Sahara region. It shows a 0.002 percent decrease in fresh groundwater loss per year in high emission scenario and 0.0014 percent decrease in fresh groundwater loss per year in low emission scenario. This suggests an increase in availability of fresh groundwater resources in coastal zones of the northern Africa and the Sahara region in the future. Table 2 summarizes the long term changes in loss of fresh groundwater resources for high and low emission scenarios.

Approximate location of Table 2

\subsection{Comparison of short term variation of loss of fresh groundwater resources and precipitation change}

Considering the selected five water resources stressed regions and the selected climate change scenarios, this study provides new insight into temporal changes in coastal fresh groundwater resources in response to climatic factors, especially precipitation. Precipitation, the primary source of groundwater recharge, is the largest term in the water balance, and is variable in both time and space. Therefore, future precipitation changes control the fresh groundwater resources variability. Annual fresh groundwater losses are well matched changes in precipitation for both high and low emission scenarios (Fig 3b, 4b). The increases in precipitation are 
followed by increases in fresh groundwater resources (reduction in loss of fresh groundwater resources). Decrease in precipitation decreases in fresh groundwater resources (increase in loss of fresh groundwater). These changes were clearly identified in the southern Asian region and the Mediterranean region, which both showed large fluctuations in annual precipitation in both scenarios. There were slight increases and decreases in precipitation projected in the Central America and southern African regions, but the annual precipitation is less and does not lead to short term change in fresh groundwater resources in the A2 scenario. However, the South African region shows short term variations for the B2 scenario.

The northern Africa / Sahara region shows that the precipitation will be increased in the future. The long term trends in fresh groundwater resources also indicate an increase in fresh groundwater resources in this region for both scenarios. Projected temperature increases are likely to lead increases in open water and soil/plant evaporation. Increased evapotranspiration affects to groundwater recharge and therefore, the rate of fresh groundwater loss is lower relative to precipitation in the North Africa region. The projected temperature changes show trends of increasing annual mean temperature in all five areas (Fig 3c and 4c). However, we did not find a clear relationship between increased temperature and fresh groundwater resources.

\subsection{Correlations between climate and loss of fresh groundwater resources}

To evaluate the correlation between climate factors and fresh groundwater resources in each region, the predicted change in precipitation and temperature under two SRES scenarios were considered. The correlation coefficient was calculated as follows; 


$$
\text { Correlation Coefficient }(\mathrm{r})=\frac{\sum_{i}^{100}\left(x_{i}-\bar{x}\right)\left(y_{i}-\bar{y}\right)}{\sqrt{\sum_{i=1}^{100}(x-\bar{x})^{2} \times \sum_{i=1}^{100}(y-\bar{y})^{2}}}
$$

where $x$ is the climate factor and $y$ is the loss of fresh groundwater resources. $i$ represents the time in steps in years.

The variation of climate variables and fresh groundwater resources are shown in Fig 5 and Fig 6. Fig 5a shows the correlation between the change in precipitation and changes in loss of fresh groundwater resources, while Fig. 5b shows the correlation between the change in temperature and changes in loss of fresh groundwater resources for the A2 scenario. Also Fig 6a shows the correlation between the change in precipitation and changes in loss of fresh groundwater resources, while Fig. 6b shows the correlation between the change in temperature and changes in loss of fresh groundwater resources for the B2 scenario.

Approximate location of Fig. 5 and Fig. 6

They indicate that only the Mediterranean and the southern Asian regions show high correlation between the precipitation and loss of fresh groundwater resources, with a correlation coefficient of 0.92 and 0.78 for high emission scenario and 0.65 and 0.68 for low emission scenario respectively. However, the changes in precipitation and related changes in fresh groundwater loss were small in the North African region. The Mediterranean and southern Asian regions show wide ranges of precipitation (over $\pm 400 \mathrm{~mm} /$ year) would lead to widely varying fresh groundwater loss. The Mediterranean region precipitation is primarily widely varying mid-latitude cyclones 
during the winter season. The southern Asian region which has a tropical and monsoon climate, the main source of precipitation is widely varying monsoon rains. In the southern Asian area, the Himalayas play a critical role in the continental monsoon and the corresponding seasonal variability in precipitation. Johns et al (2003) showed that the spatial patterns of change in both temperature and precipitation are very similar in similar latitudes. He also found that annual precipitation increased in high latitudes while precipitation increased in winter across most mid-latitude regions and temperature increases were greater at high latitudes.

The correlation between temperature and change in fresh groundwater resources was very poor in all regions for both scenarios. In general, the correlation coefficients emphasize that the precipitation and temperature individually do not show a good correlation to changes in fresh groundwater resources. Therefore the combined effects of precipitation and temperature were considered for this analysis.

\subsection{Variation of loss of fresh groundwater resources with respect to an aridity} index

Aridity indexes are quantitative indicators of the degree of water deficiency present at a given location and typically express the combined effects of water and energy in the region. Our aridity index was the ratio between mean annual precipitation and mean annual temperature (Lang's index) and a widely used modified version developed by E. de Martonne in 1925. This index also called as "Martonne index" (Oliver and Fairbridge, 1987, Pahari and Murai, 1999). 
Martonne's aridity index is defined by;

$$
A I=\frac{P}{T+10}
$$

Where $T$ is mean annual temperature $\left({ }^{0} \mathrm{C}\right)$ and $P$ is mean annual precipitation (mm)

The aridity index versus loss of fresh groundwater relationship exhibits a global negative correlation for both SRES scenarios (Fig 5c and Fig 6c). The correlation coefficients imply that the changes in climate and loss of fresh groundwater resources are correlated in the Central American, Mediterranean, southern African and southern Asian regions, with correlation coefficients higher than 0.5 for both scenarios. In the northern Africa / Sahara region, we found poor correlations between climate and fresh groundwater resources. However the variations in climate and impacts on fresh groundwater resources were small and it might lead to inconsistent estimates of regional precipitation and temperature in the northern Africa / Sahara region.

\subsection{Regional distribution of the aridity index and fresh groundwater resources}

The regional variation in the absolute value of the aridity index and loss of fresh groundwater resources under both high and low emission scenarios are shown in Fig. 7. It show that the scatter plots of aridity index versus loss of fresh groundwater resources results in clusters according to climatic zone. In both cases, the low aridity index, which corresponds to higher loss of fresh groundwater resource, was evident in the Central America and northern Africa / Sahara regions. For both scenarios, these regions show the aridity index less than 15 and are associated with the highest loss of fresh groundwater resources. The Central American region is located in 
tropical climate zone and the northern Africa / Sahara region has desert areas. The precipitation is low in both regions, having average annual precipitation less than $200 \mathrm{~mm} /$ year. In the north African / Sahara region, the rainfall might become more intense, but there likely will be more extreme events with average monthly temperatures above $30^{\circ} \mathrm{C}$ during the warmest months and extremes above $50^{\circ} \mathrm{C}$ (IPCC,1998). Desert air is very dry with intense incoming solar and outgoing terrestrial radiation resulting in large daily temperature fluctuations and high potential evaporation. The increase in evapotranspiration controls the groundwater recharge and leads to loss of fresh groundwater resources.

\section{Approximate location of Fig. 7}

The aridity index varies through wide range in the Mediterranean, South Asia, and South Africa regions for both scenarios. South Africa shows comparatively high fresh groundwater loss than other two regions. As compared to the south Asia, loss of fresh groundwater resources is also less in the Mediterranean region. The changes in precipitation across different regions of the Mediterranean can be classified according to the current and projected distributions of rainfall. There could be an increase in summer drought consistent with observed decreases in summer precipitation an increases in winter and spring (IPCC,1998). Such changes are likely to affect mainly areas that already are sensitive to drought. However in the Mediterranean region, the mean precipitation is higher and the mean temperature is lower compared to south Asian region. Therefore the mean loss of fresh groundwater resources in the Mediterranean region is also lower than in south Asian region. Table 
3 presents the statistical properties of the fresh groundwater losses in each region, which confirms the average impact on fresh groundwater resources in each area.

Approximate location of Table 3

\subsection{Impact of loss of fresh groundwater resources on socioeconomic activities}

The reduction in fresh groundwater resources could be detrimental to various waterdependent socioeconomic activities. The assessment of impacts of loss of fresh groundwater resources on society requires estimation of future water withdrawals. These withdrawals will depend not only on future population but also water demand and water use efficiency. The loss of fresh groundwater resources affects local people in water-stressed areas via increased demand resulting from population growth, water use patterns linked with life style, and degradation of watersheds caused by land-use changes. Projections of future water use vary widely, reflecting different potential population growth and water use efficiencies (Seckler et al, 1998).

SRES emission scenarios provide multiple predictions of future global and regional population and other important global-scale quantitative and qualitative socioeconomic indicators. Scenario A2, in contrast, predicts a world of lower economic development and weak globalization. Population growth in A2 is the highest (15 billion by 2100), because of the reduced financial resources available to address human welfare, child and reproductive health and education. B2 scenario assume lower population growth rate and it leads to a more optimistic world (IPCC, 2000). 
The regional SRES population projections were downscaled to the nation scale by CIESIN (2002). We estimate future population density based on the Gridded Population of the World (GPW) regional projections by CIESIN for the two selected SRES scenarios (Gaffin et al, 2003). Table 4 shows the comparison of population, fresh groundwater availability, and comparison of per capita fresh groundwater resources availability per unit aquifer thickness (1m) in year 2010 and 2100, for two selected SRES scenarios. It shows that scenario A2 predicts the highest population and the resultant highest fresh water demand. Table 4 further shows that SRES A2 represents the lowest per capita fresh groundwater resources in all regions. The interesting finding is that, even though the availability of fresh groundwater resources in the Mediterranean and south Asia is less under the B2 scenario, the per capita fresh groundwater resources is less for the A2 scenario. It emphasizes critical socio-economic problems in high populated water resources stressed areas.

\section{Approximate location of Table 4}

Regionally, South Asian countries have the highest overall population density in the world and increasing demands in the domestic, agricultural, and industrial sectors will place additional stresses on water resources. Even though the availability of fresh groundwater is relatively higher in the south Asian region, the per capita fresh water resources availability in one square kilometer of coastal area is less (468 $\mathrm{m}^{3}$ per person in 2010 under A2 scenario) and will likely decrease in future (115 m³ per person in 2100). Present and future per capita fresh water resources show relatively higher values in African continent, which have low population density. The available fresh groundwater resources are less in the African region, but the population is also 
less and per capita resources are higher. In Africa, poverty is linked to the environment in complex ways, particularly in economies that are based on exploitation of natural resources such as groundwater resources. Hence, even though it seems that the per capita fresh groundwater resources are higher on the African continent, the poor communities do not have capacity and technology to access the deep groundwater and extract them for use. Degradation of these resources reduces the productivity of poor persons who most rely on natural resources, and makes poor communities even more susceptible to extreme events. Nicholls et al (2004) shows that the global coastal population is already large and expanding rapidly (coastal population growth is twice the national population growth). Hence, the socioeconomic problems can be more critical in coastal regions.

\section{Conclusions}

The investigation of the relationship between climate change and loss of fresh groundwater resources is important for understanding the characteristics of the different regions. Among the five selected water resources stressed areas, both high and low emission scenarios provide more likely impacts on fresh groundwater resources. The relationships between precipitation, temperature, and loss of fresh groundwater resources highlight the complexity of hydrological consequences, but still indicate an increase in loss of fresh groundwater resources in all studied regions except the northern Africa/Sahara region for both high and low emission scenarios. Over the 100 years, the loss of fresh groundwater resources shows a positive 
correlation for both scenarios in Central America, the Mediterranean, South Asia, and South Africa.

The correlation between the change in climatic parameters and changes in loss of fresh groundwater resources were evaluated for both high and low emission scenarios. These correlations might be positive or negative at the continental scale, which indicates complexity in the feedback between precipitation and temperature changes in the hydrological cycle at the regional scale. In general, the correlation coefficients emphasize that the precipitation and temperature individually do not show a good correlation to changes in fresh groundwater resources. The combined effects of precipitation and temperature have been considered for the further analysis. The aridity index has been used to evaluate the combined effect of regional precipitation and temperature. The evaluation concludes that aridity index versus loss of fresh groundwater resources exhibits a global negative correlation. The scatter plots of aridity index versus loss of fresh groundwater resources show regional clustering in the scatter points. Low aridity index, which corresponds to higher loss of fresh groundwater resource, was evident in the Central America and northern Africa / Sahara regions. A wide range of aridity index appears and the loss of fresh groundwater resources is comparatively less in Mediterranean region.

Furthermore, the loss of fresh groundwater resources as a result of global warming impacts socio-economic activities in the water stressed regions. Future population growth and increased demand in the domestic, agricultural, and industrial sectors for fresh groundwater will make the situation more complex in the south Asian region. SRES A2 scenario which shows highest population growth, predicts the highest 
impact on per capita fresh groundwater resources. Even though the available per capita fresh groundwater resources are higher in African region, the poor communities do not have capacity and technology to access natural resources such as groundwater. The degradation of these resources further reduces the productivity of poor public.

\section{Acknowledgements}

This work was made possible through the grants from Grant-in-Aid for Scientific Research for JSPS (Prof. Nobuo Mimura) and Global Environment Research Fund. The authors would like to acknowledge the generosity of those grants. We also thank Dr. Brian McGlynn and two anonymous referees for providing detailed and constructive suggestions and comments on the manuscript. 


\section{References}

Arnell,N,W,. 1999, Climate change and global water resources, Global Environmental Change 9, S31-S49.

Arnell,N,W,. 2004, Climate change and global water resources: SRES emissions and socio-economic scenarios, Global Environmental Change 14, 31-52.

Arnell, N,W., 2004, Livermore, M.J.L., Kovatsc, S., Levy, P.E ., Nicholls, R., Parry, M.L., Climate and socio-economic scenarios for global-scale climate change impacts assessments: characterising the SRES storylines, Global Environmental Change 14, 3-20.

Bear, J., Cheng, A.H.D., Sorek, S., Ouazar, D., and Herrera, I., 1999, Seawater Intrusion in Coastal Aquifers- Concepts, Methods and Practices, Kluwer Academic Publishers.

Bobba, A.G., Singh, V.P., Jeffries, D.S., and Bengtsson, L., 1997, Application of a watershed runoff model to north-east pond river, Newfoundland: to study water balance and hydrological characteristics owing to atmospheric change. Hydrological processes 12 ,1573-1593.

CIESIN, 2002, Center for International Earth Science Information Network, Columbia University,. Gridded Population of the World (GPW), CIESIN, Columbia University, Palisades, NY. ( http://sedac.ciesin.org/plue/gpw) DETR, 1997, Climate change and its impacts, Department for Environment, Transport, and the Regions, The UK Programme,. HMSO, The Met Office, London. 
Eckhardta, K., Ulbrichb, U., 2003, Potential impacts of climate change on groundwater recharge and stream flow in a central European low mountain range, Journal of Hydrology 284, 244-252.

Essaid, H.I., 1990, A Multilayered sharp interface Model of coupled freshwater and saltwater flow in coastal systems: Model development and application, Water Resources Research, 26, 431 -1455.

FAO-SDRN Agrometeorology Group. 1997. Köeppen climate zones, FAO Environment and Natural Resources Service (SDRN), Global climate maps series. (http://www.fao.org/sd/eidirect/CLIMATE/EIsp0001.html)

Gaffin, S.R., Xing, X., Yetman, G., 2004, Downscaling and geo-spatial gridding of socio-economic projections from the IPCC Special Report on Emissions Scenarios (SRES). Global Environmental Change, 14, 105-123.

Gertena, D., Schaphoffa, S., Haberlandtb, U., Luchta, W., Sitcha, S., 2004, Terrestrial vegetation and water balance-hydrological evaluation of a dynamic global vegetation model, Journal of Hydrology 286, 249-270.

Gleick , P.H., 1986, Methods for evaluating the regional hydrologic impacts of global climatic change. Journal of Hydrology 88, 97-116.

Hitz, S., Smith, J., 2004, Estimating global impacts from climate change, Global Environmental Change 14, 201-218.

Hulme, M., Mitchell, J., Ingram, W., Lowe, J., Viner, D., 1999, Climate change scenarios for global impacts studies, Global Environmental Change 9, S3-S19.

IPCC, 1998, The Regional Impacts of Climate Change: An Assessment of Vulnerability,1998, Watson, R.T., Zinyowera, M.C., Moss, R.H. and Dokken, D.J., (Eds), Intergovernmental Panel on Climate Change, Cambridge University Press, Cambridge, UK. 
IPCC, 2000, Emissions Scenarios: A Special Report of Working Group II of the Intergovernmental Panel on Climate Change, Nakicenovic, N., Swart, R. (Eds.), Cambridge Univ. Press, Cambridge, Cambridge, UK.

IPCC, 2001, Climate Change 2001: The Scientific Basis. Contributions of Working Group 1 to the Third Assessment Report of the Intergovernmental Panel on Climate Change, Houghton, J.T., Ding, Y., Griggs, D.J., Noguer, M., van der Linden, P.J. , Dai, X., Maskell, K., and Johnson, C.A., (Eds), Cambridge University Press, Cambridge, UK.

Johns, T.C., Gregory, J.M., Ingram, W.J., Johnson, C.E., Jones, A.,Lowe, J.A., Mitchell, J.F.B., Roberts, D.L., Sexton, D.M.H., Stevenson, D.S., Tett, S.F.B., Woodage, M.J., 2003, Anthropogenic climate change for 1860 to 2100 simulated with the HadCM3 model under up-dated emissions scenarios. Climate Dynamics 20, 583-612.

Labat, D., Godd, Y., Probst, J.L., Guyot, J.L., 2004, Evidence for global runoff increase related to climate warming, Advances in Water Resources 27, 631-642.

Loaiciga, H.A., Valdes, J.B., Vogel, R., Garvey, J., Schwarz, H., 1996, Global warming and the hydrologic cycle, Journal of Hydrology 174, 83 -127

Mimikou, M.A., Baltas, E., Varanou E., and Pantazis, K., 2000, Regional impacts of climate change on water resources quantity and quality indicators. Journal of Hydrology 234, 95-109.

Najjar, R.G., 1999, The water balance of the Susquehanna River Basin and its response to climate change. Journal of Hydrology 219, 7-19.

Nicholls, R.J., Lowe, J.A., 2004, Benefits of mitigation of climate change for coastal areas, Global Environmental Change 14, 229-244 
Oliver J. E., Fairbridge R W., (Eds), 1985, The encyclopedia of Climatology, Encyclopedia of earth sciences, Volume XI, Van Nostrand Reinhold Publishers, New York.

Pahari, K., and Murai, S., 1999, Modelling for prediction of global deforestation based on the growth of human population, Journal of Photogrammetry and Remote Sensing, 54, 317-324.

PSMSL : Permanent Service for Mean Sea Level data set, Proudman Oceanographic Laboratory (POL), (http://www.pol.ac.uk/psmsl/) Ranjan S.P., Kazama, S., Sawamoto, M., 2004, Effects of climate and land use changes on groundwater resources in coastal aquifers, Journal of Environmental Management, Submitted for publication

Reilly, T.E., Goodman, A.S., 1985, Quantitative analysis of fresh-salt water relationship in groundwater systems- A historical perspective, Journal of Hydrology, 80, 125-149.

Remson, I., Hornberger, G.M., Molz, F.I., 1971, Numerical methods in subsurface hydrology: with an introduction to the finite element method, pp389.

Seckler, D., Amarasinghe, U., Molden, D., de Silva, R., Barker, R., 1998. World Water Demand and Supply, 1990 to 2025: Scenarios and Issues. International Water Management Institute Research Report 19, Sri Lanka.

Semmler, T., and Daniela Jacob, 2004, Modeling extreme precipitation events; A climate change simulation for Europe, Global and Planetary Change 44, 119127. 


\section{Tables}

Table 1. Characteristics of selected water resources stressed regions

\begin{tabular}{|c|c|c|c|c|c|}
\hline \multirow{2}{*}{ Region } & \multirow{2}{*}{ Climate region $^{\text {a }}$} & \multirow{2}{*}{$\begin{array}{c}\text { Related } \\
\text { groundwater } \\
\text { region } \\
\text { reg }\end{array}$} & \multicolumn{2}{|c|}{$\begin{array}{c}\text { Characteristics of coastal } \\
\text { aquifers b }\end{array}$} & \multirow{2}{*}{$\begin{array}{c}\text { Sea level } \\
\text { rise }^{c}\end{array}$} \\
\hline & & & $\begin{array}{l}\text { Geological } \\
\text { formation }\end{array}$ & $\begin{array}{c}\text { Hydraulic } \\
\text { conductivity }\end{array}$ & \\
\hline $\begin{array}{l}\text { Central } \\
\text { America } \\
\text { (CAM) }\end{array}$ & Tropical & $\begin{array}{l}\text { North and } \\
\text { Central } \\
\text { America }\end{array}$ & $\begin{array}{l}\text { Sedimentary and } \\
\text { alluvial deposits }\end{array}$ & $10^{-3}-10^{-5} \mathrm{~m} / \mathrm{s}$ & $\begin{array}{c}2.0 \\
\mathrm{~mm} / \text { year }\end{array}$ \\
\hline $\begin{array}{l}\text { Southern } \\
\text { Africa (SAF) }\end{array}$ & $\begin{array}{l}\text { Mediterranean/ } \\
\text { subtropical }\end{array}$ & $\begin{array}{l}\text { Sub Saharan } \\
\text { basins }\end{array}$ & $\begin{array}{l}\text { Crystalline rocks } \\
\text { and sedimentary } \\
\text { deposits }\end{array}$ & $10^{-4}-10^{-5} \mathrm{~m} / \mathrm{s}$ & $\begin{array}{c}1.5 \\
\mathrm{~mm} / \text { year }\end{array}$ \\
\hline $\begin{array}{l}\text { Northern } \\
\text { Africa / } \\
\text { Sahara (HAS) }\end{array}$ & Desert & $\begin{array}{l}\text { North African } \\
\text { Basins }\end{array}$ & $\begin{array}{l}\text { Marine } \\
\text { sediments, } \\
\text { Eolian sand and } \\
\text { alluvial deposits }\end{array}$ & $10^{-3}-10^{-4} \mathrm{~m} / \mathrm{s}$ & $\begin{array}{c}1.65 \\
\mathrm{~mm} / \text { year }\end{array}$ \\
\hline $\begin{array}{l}\text { Mediterranean } \\
\text { (MED) }\end{array}$ & Mediterranean & $\begin{array}{l}\text { Southern } \\
\text { Europe and } \\
\text { Atlas } \\
\text { Mountains }\end{array}$ & $\begin{array}{l}\text { Limestone, } \\
\text { sandstone and } \\
\text { unconsolidated } \\
\text { sediments }\end{array}$ & $10^{-4}-10^{-5} \mathrm{~m} / \mathrm{s}$ & $\begin{array}{c}2.5 \\
\mathrm{~mm} / \text { year }\end{array}$ \\
\hline $\begin{array}{l}\text { Southern Asia } \\
\text { (SAS) }\end{array}$ & $\begin{array}{l}\text { Tropical / } \\
\text { Monsoon }\end{array}$ & $\begin{array}{l}\text { Peninsular } \\
\text { India }\end{array}$ & $\begin{array}{l}\text { Sedimentary } \\
\text { rocks and } \\
\text { unconsolidated } \\
\text { sediments }\end{array}$ & $10^{-4}-10^{-5} \mathrm{~m} / \mathrm{s}$ & $\begin{array}{c}0.9 \\
\mathrm{~mm} / \text { year }\end{array}$ \\
\hline
\end{tabular}

Source: (a) Koeppen's Climate Classification (FAO) ; (b) Global Groundwater regions, IGRAC ; (c) Permanent Service for Mean Sea Level (PSMSL) 
Table 2 Long-term trends of fresh groundwater loss for high and low emission scenarios

\begin{tabular}{|l|c|c|}
\hline \multirow{2}{*}{} & \multicolumn{2}{|l|}{ Rate of change of fresh groundwater loss (\% per year) } \\
\cline { 2 - 3 } & High emission scenario ( A2) & low emission scenario ( B2) \\
\hline Central America & 0.015 & 0.02 \\
\hline Mediterranean & 0.028 & 0.0005 \\
\hline North Africa & -0.0002 & -0.0014 \\
\hline South Africa & 0.027 & 0.022 \\
\hline South Asia & 0.075 & 0.078 \\
\hline
\end{tabular}

Table 3. Statistical behavior of fresh groundwater resources

\begin{tabular}{|l|c|c|c|c|c|c|c|c|c|c|}
\hline \multirow{3}{*}{$\begin{array}{l}\text { Statistical } \\
\text { parameters }\end{array}$} & \multicolumn{8}{|c|}{ Fresh groundwater loss $\left(\mathrm{m}^{3} \mathrm{~km}^{-2}\right)$} \\
\cline { 2 - 11 } & \multicolumn{4}{|c|}{ High emission scenario (A2) } & \multicolumn{4}{|c|}{ Low emission scenario (B2) } \\
\cline { 2 - 11 } & CAM & MED & SAH & SAF & SAS & CAM & MED & SAH & SAF & SAS \\
\hline Mean & 96.0 & 81.5 & 98.2 & 93.5 & 90.5 & 94.8 & 81.3 & 98.8 & 94.4 & 91.5 \\
\hline Standard Deviation & 2.0 & 3.0 & 0.5 & 2.1 & 3.8 & 2.3 & 3.3 & 0.3 & 2.2 & 3.4 \\
\hline
\end{tabular}

Table 4. Population and fresh groundwater availability in water resource stressed regions

\begin{tabular}{|c|c|c|c|c|c|c|c|}
\hline \multirow[b]{2}{*}{$\begin{array}{l}\text { Emission } \\
\text { scenario }\end{array}$} & \multirow[b]{2}{*}{ Region } & \multicolumn{3}{|c|}{2010} & \multicolumn{3}{|c|}{2100} \\
\hline & & $\begin{array}{l}\text { Population } \\
\text { density }\end{array}$ & \begin{tabular}{|l|} 
Fresh \\
groundwate \\
availability \\
$\left(\mathrm{m}^{3}\right.$ per \\
$\left.\mathrm{km}^{2}\right)$
\end{tabular} & $\begin{array}{l}\text { Per capita } \\
\text { resources } \\
\text { ( } \mathrm{m}^{3} / \text { cap/year) }\end{array}$ & $\begin{array}{l}\text { Population } \\
\text { density }\end{array}$ & \begin{tabular}{|l|} 
Fresh \\
groundwater \\
availability \\
$\left(\mathrm{m}^{3}\right.$ per \\
$\left.\mathrm{km}^{2}\right)$
\end{tabular} & $\begin{array}{l}\text { Per capita } \\
\text { resources } \\
\text { (m³/cap/year) }\end{array}$ \\
\hline \multirow{5}{*}{ A2 } & $\begin{array}{c}\text { Central } \\
\text { America }\end{array}$ & 120 & 64000 & 533.3 & 200 & 25000 & 125.0 \\
\hline & Mediterranean & 82 & 195000 & 2378.0 & 150 & 178000 & 1186.7 \\
\hline & North Africa & 11 & 12000 & 1090.9 & 18 & 15000 & 833.3 \\
\hline & South Africa & 18 & 67000 & 3722.2 & 26 & 39000 & 1500.0 \\
\hline & South Asia & 250 & 117000 & 468.0 & 450 & 52000 & 115.6 \\
\hline \multirow{5}{*}{ B2 } & $\begin{array}{c}\text { Central } \\
\text { America }\end{array}$ & 116 & 79000 & 681.0 & 140 & 45000 & 321.4 \\
\hline & Mediterranean & 80 & 180000 & 2250.0 & 112 & 175000 & 1562.5 \\
\hline & North Africa & 10 & 9000 & 900.0 & 16 & 15000 & 937.5 \\
\hline & South Africa & 12 & 76000 & 6333.3 & 19 & 45000 & 2368.4 \\
\hline & South Asia & 200 & 110000 & 550.0 & 300 & 35000 & 116.7 \\
\hline
\end{tabular}




\section{Illustrations}

Fig 1. Schematic representing the loss of fresh groundwater resources due to salinity intrusion in coastal aquifers

Fig 2. (a) Selected water resource stressed areas (Aller et al, 1999);

(b) Representation of coastal boundary in HadCM3 resolution

Fig 3. Average annual variation of (a) loss of fresh groundwater resource,

(b) precipitation and (c) temperature for SRES A2 scenario

Fig 4. Average annual variation of (a) loss of fresh groundwater resource,

(b) precipitation and (c) temperature for SRES B2 scenario

Fig. 5. Correlation between (a) precipitation versus loss of fresh groundwater resource (b) temperature versus loss of fresh groundwater resource and (c) aridity index versus loss of fresh groundwater resource for A2 scenario

Fig. 6. Correlation between (a) precipitation versus loss of fresh groundwater resource (b) temperature versus loss of fresh groundwater resource and (c) aridity index versus loss of fresh groundwater resource for B2 scenario

Fig. 7. Scatter plot of the change in aridity index and loss of fresh groundwater resource in different climate regions (a) for A2 scenario, (b) for B2 scenario 


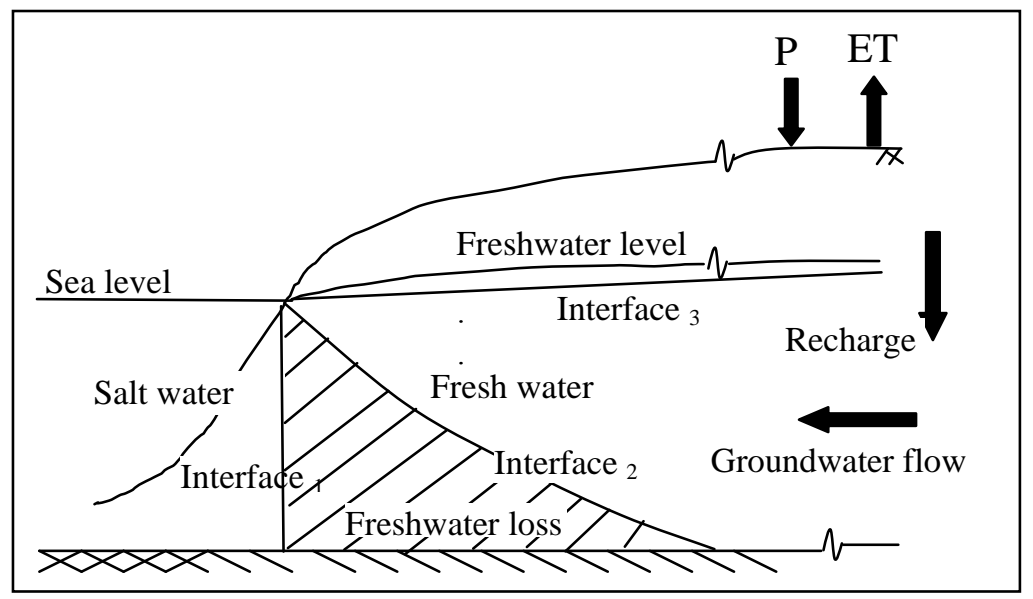

Fig 1. Schematic representing the loss of fresh groundwater resources due to salinity intrusion in coastal aquifers
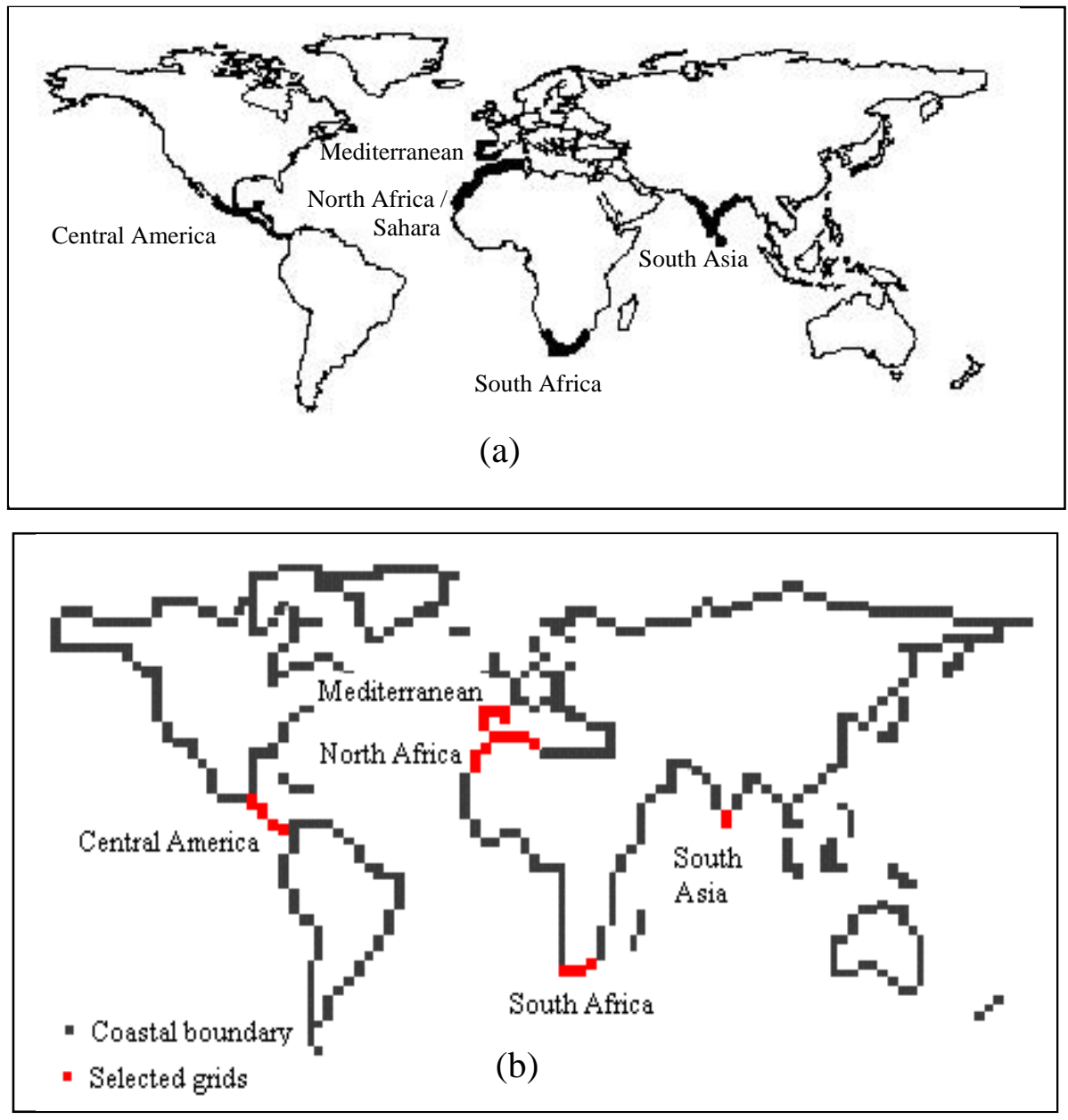

Fig 2. (a) Selected water resource stressed areas (Aller et al, 1999) ; (b) Representation of coastal boundary in HadCM3 resolution 

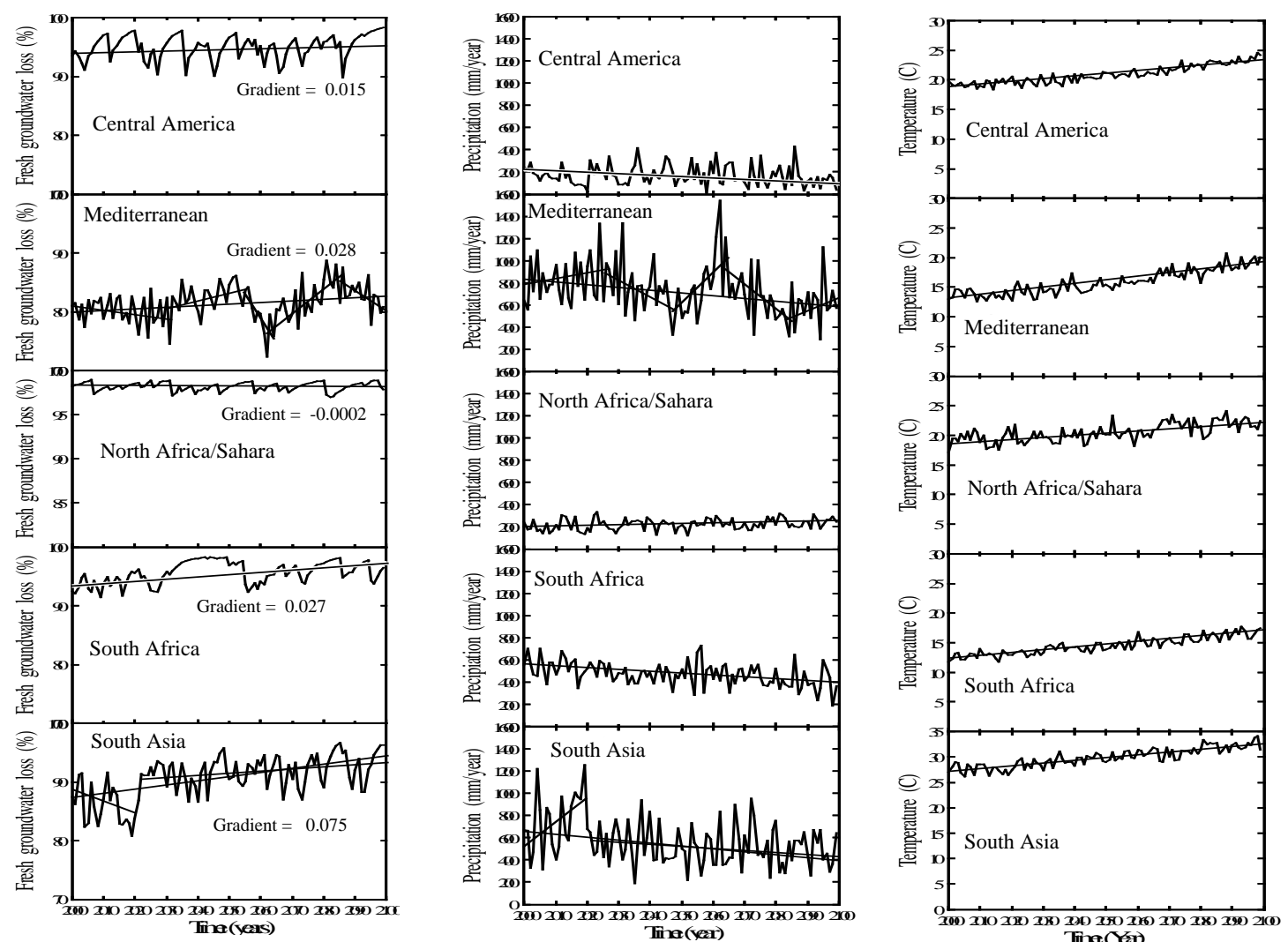

Fig 3. Average annual variation of (a) loss of fresh groundwater resource, (b) precipitation and (c) temperature for SRES A2 scenario 

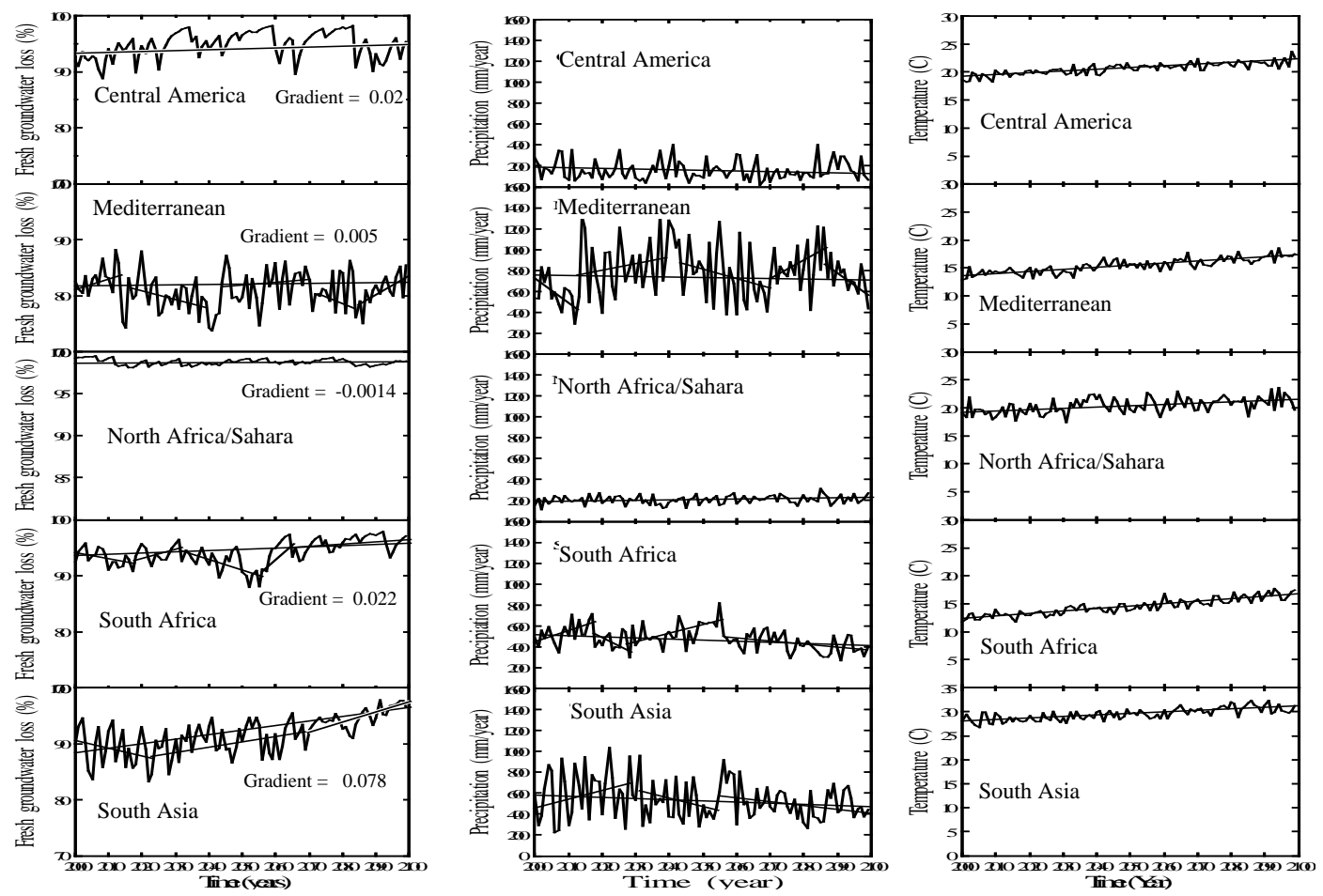

Fig 4. Average annual variation of (a) loss of fresh groundwater resource, (b) precipitation and (c) temperature for SRES B2 scenario 

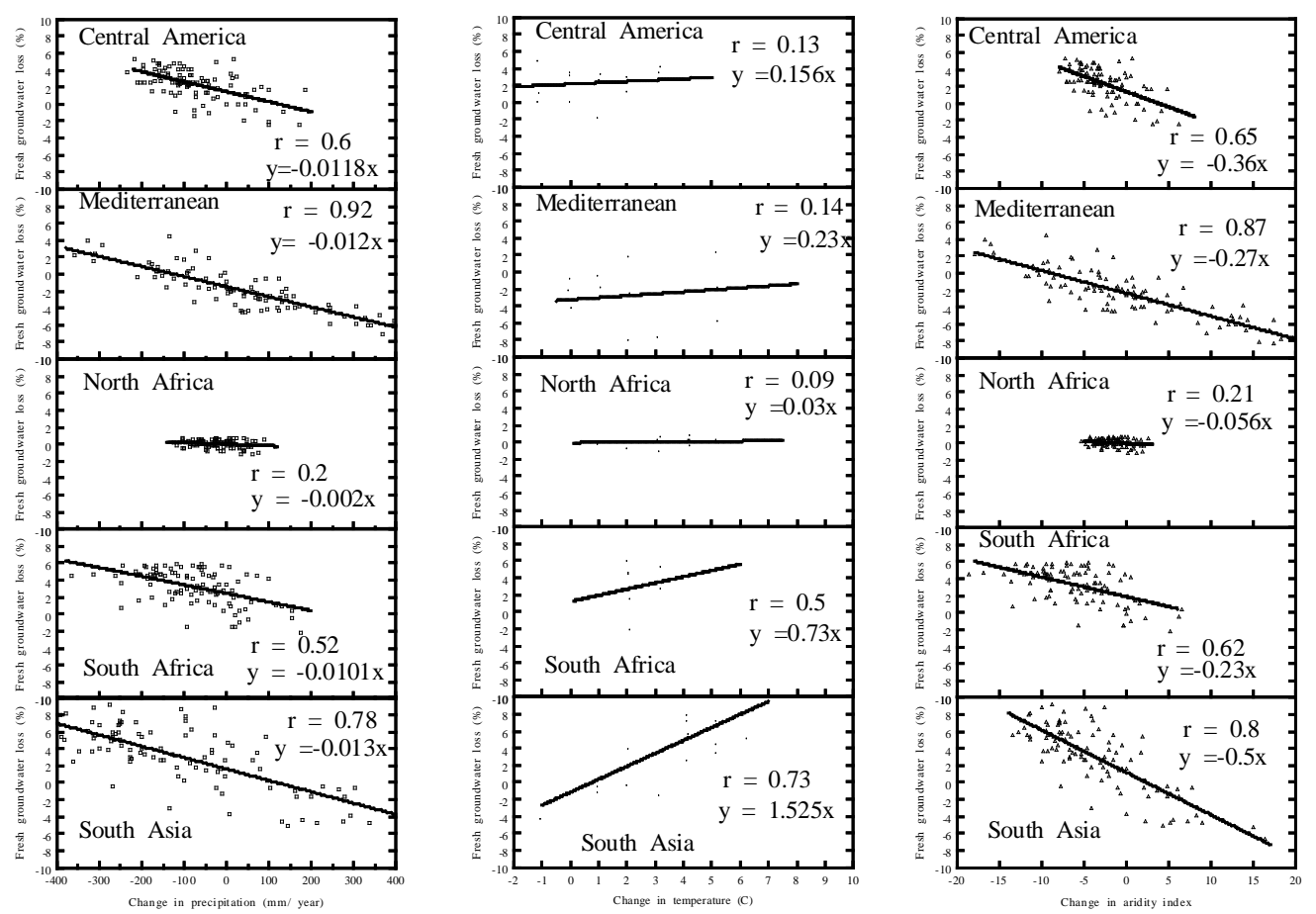

Fig. 5. Correlation between (a) precipitation versus loss of fresh groundwater resource (b) temperature versus loss of fresh groundwater resource and (c) aridity index versus loss of fresh groundwater resource for A2 scenario 

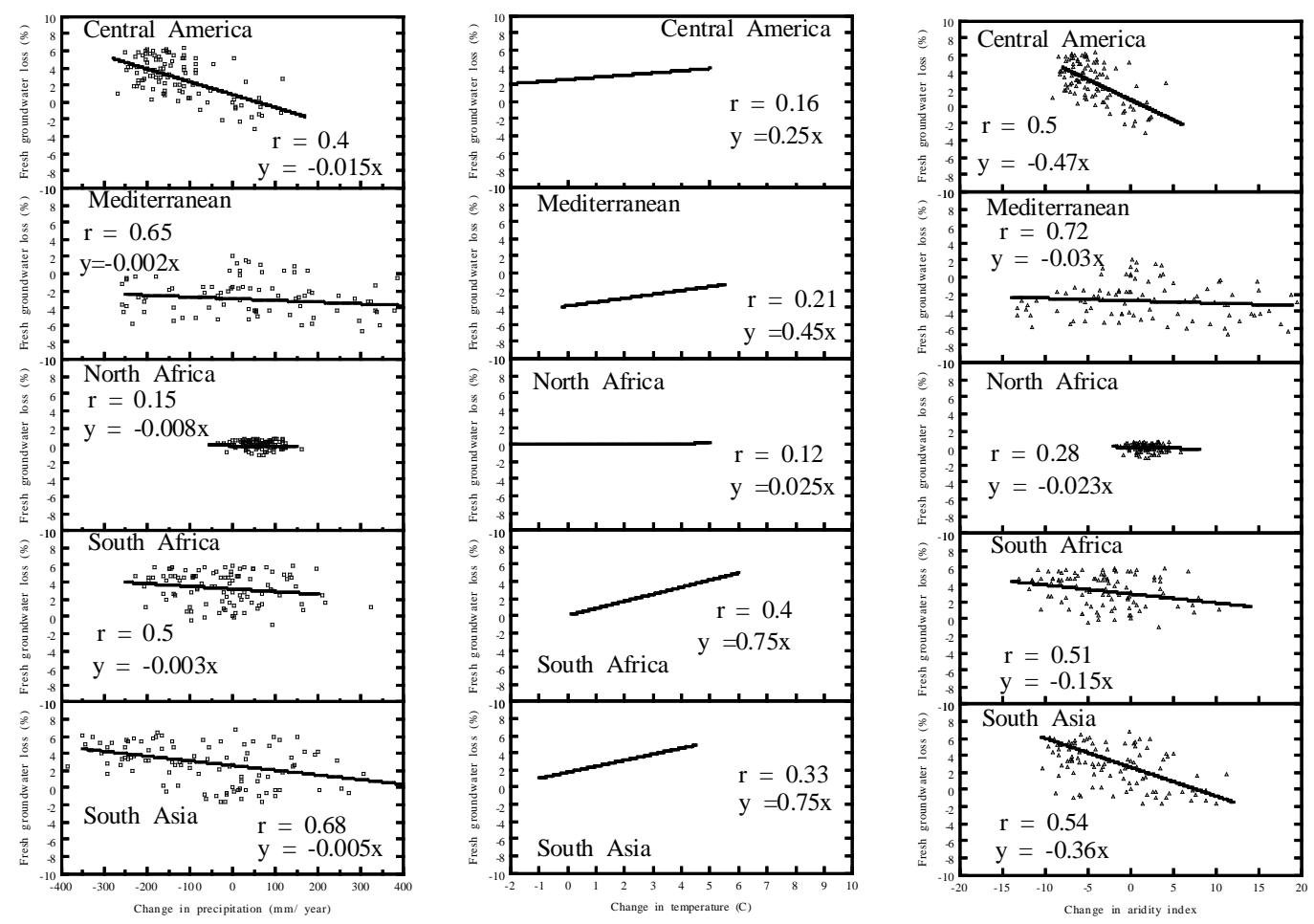

Fig. 6. Correlation between (a) precipitation versus loss of fresh groundwater resource (b) temperature versus loss of fresh groundwater resource and (c) aridity index versus loss of fresh groundwater resource for B2 scenario 


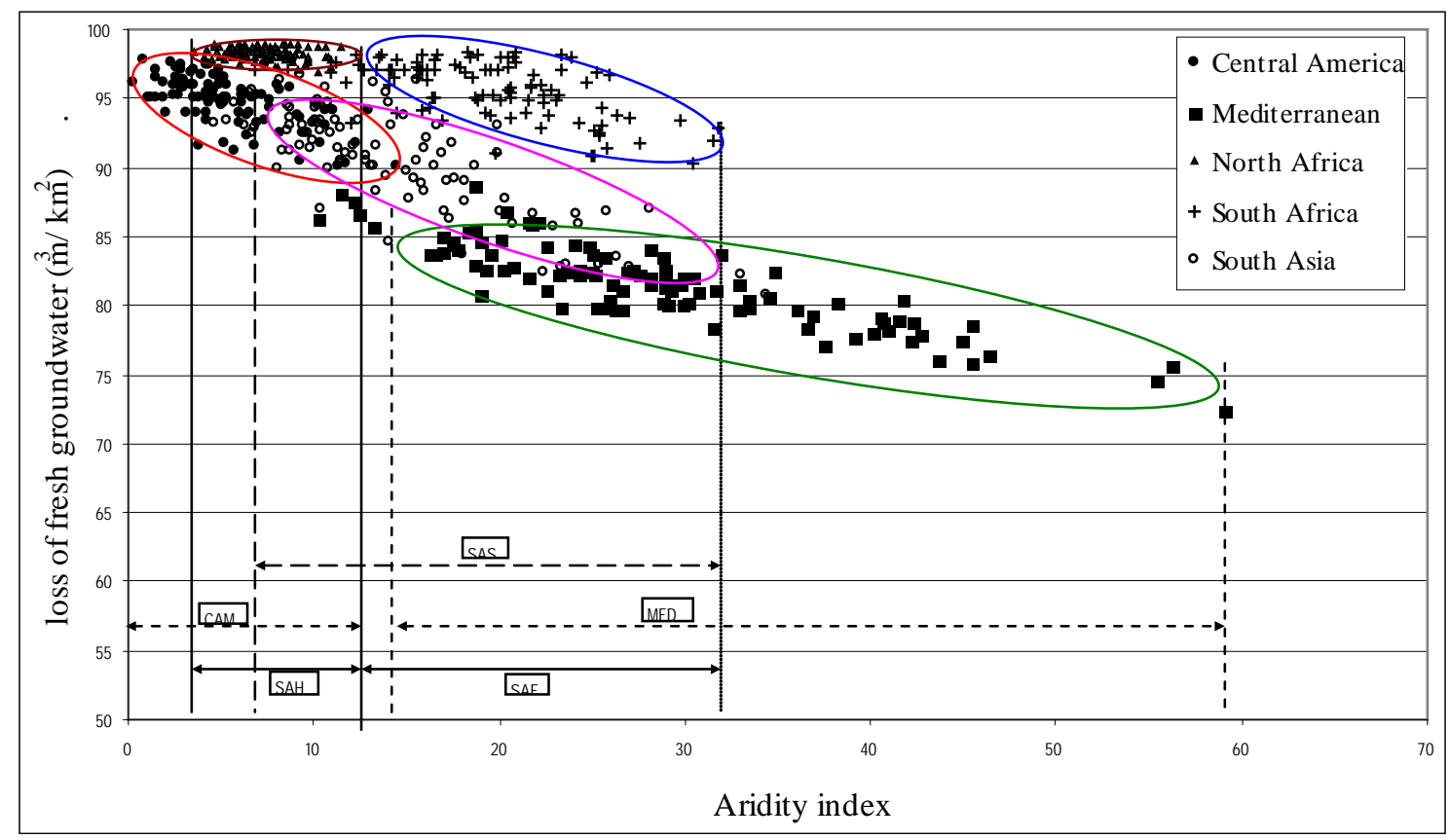

(a)

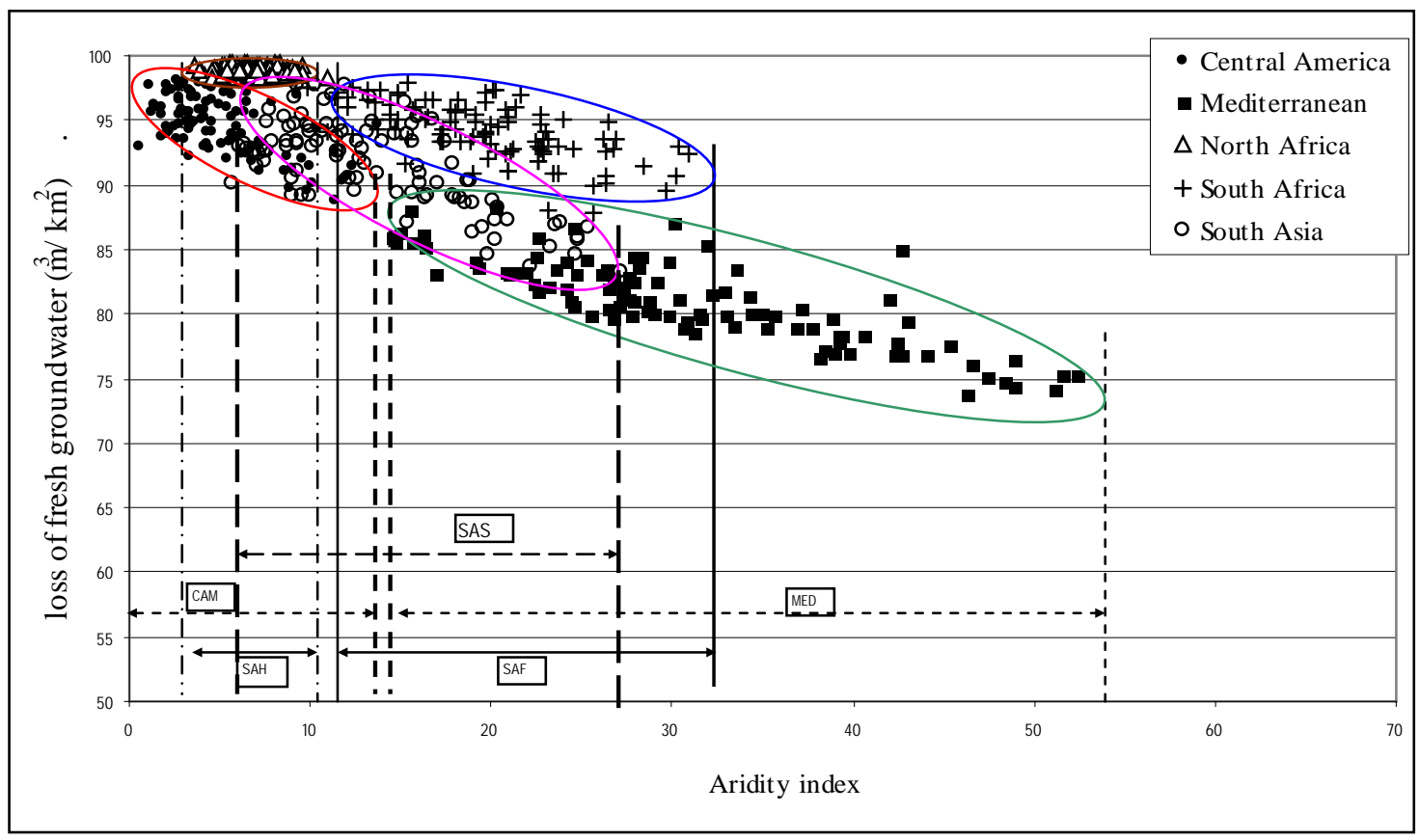

(b)

Fig. 7. Scatter plot of the change in aridity index and loss of fresh groundwater resource in different climate regions (a) for A2 scenario, (b) for B2 scenario 